\title{
Investigating the Relationship between Service Quality and Customer Satisfactio (Case Study: Passengers of Kaveh and Sofeh Terminals in Isfahan)
}

\section{Iraj Irankhah Namini $^{1^{*}}$, Asma Bahranifard ${ }^{2}$ Fariba Adibi $^{3}$}

\author{
${ }^{1}$ MBA at the University of Shahid Bahonar Kerman, Iran, Management and Economy \\ Faculty, Dneshgah Blvd. Kerman, Iran E-mail: ir.irankhah@yahoo.com \\ ${ }^{2}$ Student of Health \& Emergency Management in Disasters, Shakhes pajooh Institute, \\ Isfahan University, Isfahan, Iran 09130296295 Email : bahranifard.asma@ yahoo.com \\ ${ }^{3}$ MBA at the University of Isfahan, Iran, Management Faculty, Dneshgah St, Isfahan, \\ Iran -Email: adibi.fariba@yahoo.com
}

\begin{abstract}
The aim of this study was to evaluate the nature of relationship between service quality and customers' satisfaction thorough SERVQUAL model. This study can be considered as an applied research, from purpose point of view and descriptive-survey, with regards to the nature and method. Passengers of Kaveh and Sofeh terminal in Isfahan have been considered as research population. Sample size included 200 passengers witch was determined by Cochran formula. Spss 19 was used to analyze collected data. Results show that there is a significant positive relationship between service quality and customers' satisfaction. It is also proved that in terms of the importance of satisfactions' dimensions, assurance is the most important aspect and then reliability, empathy, equipment appearance and responsiveness in sequence are the most important dimensions.
\end{abstract}

Keywords: Bus, Customer satisfaction, Intercity terminal, SERVQUAL Model 


\section{Introduction}

Today, one of the principles of competition in customer based organizations is customer satisfaction because the key driver for organizations which are looking for a major improvement in their performance, are organizations' clients. Customer satisfaction is the result of a comparison of customer expectations and perceived and expected performance with actual performance and the cost that is paid (beerli\&etall,2004).

In the service industry in which offering services requires proper interaction with clients, overall customer satisfaction is based on how they feel about their communication with the organization. According to Kotler and Armstrong (1999) service is a subtle and impalpable activity or benefit which is offered by one side to the other side of the exchange without any kind of ownership. Improving service quality increases the likelihood of customer satisfaction which leads to behavioral outcomes such as commitment, desire to stay, bidirectional link between the service provider and the customer, increasing positive advertisement and customer's tolerance toward deficiency in service delivery(Arasli, Katircioglu, \& Samadi, 2005)

Due to population growth and intense changes in science and technology, demand of people to travel and use public transportation systems is more than ever. Thus transportation agencies as a type of service organizations had better focus on improving provided services and supplying physical and mental health for passengers.

Today retaining current customers is extremely important because attracting a new customer costs five times higher than retaining existing customers. For transportation organizations, like other service organizations, increasing customer satisfaction means to maintain market share, increase use of the system, attract new customers and create a positive public image. Attaining these goals requires reliable and efficient methods to identify the factors determining the quality of transport services from the view point of passengers(O.A.budiono, 2009).

Thus because of the importance of customer satisfaction in success of transportation agencies as a types of service organizations, this study has tried to investigate the relationship between 
service quality provided by bus transportation system and passengers' satisfaction. Thus in developing this paper we will start with a brief review of customer satisfaction, satisfaction paradigms and service quality. After that we will present our theoretical point of view and propositions and finally we will end up with contributions and conclusions of this research.

\section{Literature Review}

\section{Customer Satisfaction}

Recently new developments has caused services get improved with a high speed. In fact, today, service sector has the highest share in the economy of societies(Mirghafuri and Maleki, 2008).

The main key to gain competitive advantage in transportation industry is offering high quality services to passengers, which leads to profitability and sustainable development in companies(Chen, 2008).Previous researches proved that Key strategy for success and survival of any business enterprise is providing high quality services to customers(Ravichandran, Prabhakaran and Arun Kumar,2010).

Customer satisfaction is the feeling or attitude towards a particular product or service after using it. Satisfaction and service quality are often considered as functions of customer perceptions and expectations. Customer satisfaction is determined by the customer's perception of quality and his/her expectations and preferences(Siadat, 2008).

After 1980, the basic concepts and models for measuring consumer satisfaction and dissatisfaction among service industries include transportation industry were developed (Buchanan \& Partners, 2004 ).

In November 2002 and 2003 a national survey was taken to assess passengers' satisfaction and attitudes towards bus service in Scotland. The purpose of this study was to monitor changes in satisfaction level in different periods which provided a clearer picture of bus service and adjusted policy development and decisions about future according to the needs of travelers(Budiono,2009).

Eboli and Mazulla in 2007, examined sixteen important features of services affecting passengers' satisfaction in bus transportation system of Cosenza state in Italy. These features include 
availability of the bus, route characteristics, frequency, reliability, equipment of bus station, bus overcrowding, cleanliness, cost, information, enhancing safety while getting in the bus, personal safety, employees, complaints, maintenance of stations and protection of environment. Results proved that reliability, frequency, information, promotion, employees and complaints are the most influential factors.

Fellesson and Friman in 2008 through a comparison of transportation services in eight European cities investigated perceived satisfaction among passengers and came in a result that bus and bus stations' design cause passengers' comfort and make them enjoy their trip and provide safety against accidents(Budiono,2009).

Depending on the purpose of the travel, passengers have different expectations from transportations companies(jafari ,2002) Definition of quality of service from the view point of customers can be useful for the transportation Industry.

\section{Customer satisfaction paradigms}

\section{- Expectation - Mismatch Paradigm}

This paradigm expresses that customers/consumers have some expectations from a particular product or service and after using that they usually compare the function of the product/service with their previous expectations. If the expectations and perceived performance differ with each other, a kind of non-approved or non-compliance is occurred. If the perceived performance is better than the expectations thus the observed non-compliance is positive and it is negative, when expectations is greater than perceived performance and in case of receiving performance which equals with expectations, there is no non-compliance(Martin,1976).

\section{- Emotions Paradigm}

Customers evaluate goods and services not only based on rational calculations but also through considering the mental needs and desires, experiences and learning effects. It means regardless of the actual distance between performance and expectations, consumers may not be satisfied due to emotional reasons(Martin,1976).

- Equality Paradigm 
This paradigm which is used for retail transactions expresses that consumer satisfaction is based on the fairness of costs which are taken and predicted rewards (John,1982).

- Perceived Performance Paradigm

For some products (e.g. some durable goods) consumer satisfaction is mainly determined by product performance (based on customer perceptions) and is independent of initial expectations (Erevelles,1992).

- Multiple Processes Paradigm

Consumers, in some cases, apply multiple standards or procedures for comparisons. This concept which suggests customer satisfaction is a complex process requires much more research( Erevelles, 1992).

- Attribution Paradigm

Consumers tend to find reasons for the success or failure of their purchase and associate these causes to their purchase consequents using a multi-dimensional schema. After purchased responses of consumers are depends on these attributions. This paradigm is used to investigate the customers' grievance and complaints( Erevelles,1992).

\section{Service Quality}

Osman and Un (2002) define service quality as the degree of difference between the customers' perceptions and expectations of the services(Mishkin,2001). Service quality has a close relationship with customer satisfaction.

Service quality is known as one of the effective ways to achieve strategic benefits such as customer retention rate, increasing efficiency and achieving operating profit(Sadiq Sohail \& Shaikh, 2008).

Improving service quality increases the likelihood of customer satisfaction which leads to behavioral outcomes such as commitment, desire to stay, bidirectional link between the service 
provider and the customer, increasing positive advertisement and customer's tolerance toward deficiency in service delivery(Arasli, Katircioglu, \& Samadi, 2005)

Most researches on service quality have tested this variable through the use of SERVQUAL model or its modified model.

\section{SERVQUAL Model}

The most common model for measuring service quality is SERVQUAL scale presented by Parasuraman et al (1988), based on the gap model(Holdford David 2003).

Most researchers have applied the dimensions of the SERVQUAL model to measure traditional service quality. These dimensions are empathy, responsiveness, reliability, assurance and tangibles(Zhu et al.2002).

Table 1 shows the variables of these dimensions.

Table 1 SERVQUAL model dimensions and their variables

\begin{tabular}{|c|c|c|c|c|}
\hline empathy & assurance & responsiveness & reliability & Tangibles \\
\hline $\begin{array}{l}\text { Paying enough } \\
\text { attention to } \\
\text { customers }\end{array}$ & $\begin{array}{l}\text { Creating } \\
\text { Confidence in } \\
\text { customers }\end{array}$ & $\begin{array}{l}\text { Telling the exact } \\
\text { time of doing the } \\
\text { work to customer }\end{array}$ & $\begin{array}{l}\text { Doing the work } \\
\text { on time }\end{array}$ & $\begin{array}{l}\text { Having modern } \\
\text { equipment }\end{array}$ \\
\hline $\begin{array}{l}\text { Convenient hours } \\
\text { for customers }\end{array}$ & $\begin{array}{l}\text { Create peace of } \\
\text { mind for } \\
\text { customers in } \\
\text { every deal }\end{array}$ & $\begin{array}{c}\text { Deliver prompt } \\
\text { service }\end{array}$ & $\begin{array}{l}\text { Sincere interest in } \\
\text { solving customer } \\
\text { problems }\end{array}$ & $\begin{array}{c}\text { Attractive } \\
\text { appearance of } \\
\text { physical facilities }\end{array}$ \\
\hline $\begin{array}{l}\text { Personal attention } \\
\text { to customers }\end{array}$ & $\begin{array}{l}\text { Respecting the } \\
\text { customers }\end{array}$ & $\begin{array}{l}\text { Constant desire } \\
\text { to serve the } \\
\text { customer }\end{array}$ & $\begin{array}{l}\text { Perform right } \\
\text { services the first } \\
\text { time }\end{array}$ & $\begin{array}{c}\text { neat and tidy } \\
\text { appearance for } \\
\text { employee services }\end{array}$ \\
\hline $\begin{array}{l}\text { Liking the } \\
\text { customers }\end{array}$ & \multirow{2}{*}{$\begin{array}{c}\text { Having the } \\
\text { knowledge to } \\
\text { answer customer } \\
\text { questions }\end{array}$} & \multirow{2}{*}{$\begin{array}{l}\text { Spending } \\
\text { enough time for } \\
\text { customers }\end{array}$} & $\begin{array}{l}\text { Perform the } \\
\text { service at the } \\
\text { promised time }\end{array}$ & \multirow{2}{*}{$\begin{array}{l}\text { Attractive } \\
\text { appearance of } \\
\text { booklets. }\end{array}$} \\
\hline $\begin{array}{l}\text { Understanding the } \\
\text { specific needs of } \\
\text { customers }\end{array}$ & & & $\begin{array}{l}\text { Record of } \\
\text { documents }\end{array}$ & \\
\hline
\end{tabular}




\begin{tabular}{|l|l|l|l|}
\hline & & without error \\
\hline
\end{tabular}

\section{Research Methodology}

Research Hypothesis: Today the concept of customer satisfaction plays a vital role in gaining competitive advantage and keeping up with competitors. Besides recently due to the population growth and people tendency to travel around the world, public transportation organizations have been trying to convince the passengers using their services. Thus because of the importance of service quality in making customers loyal, this study has strived to investigate the relationship between service quality and customer satisfaction.

In the following we will develop our hypotheses:

H1: There is a positive relationship between service quality and customer satisfaction.

H1a: There is a positive relationship between equipment appearance and customer satisfaction.

H1b: There is a positive relationship between reliability and customer satisfaction.

H1c: There is a positive relationship between responsiveness and customer satisfaction.

H1d: There is a positive relationship between assurance and customer satisfaction.

H1e: There is a positive relationship between empathy and customer satisfaction.

Figure 1 shows the conceptual model of this study.

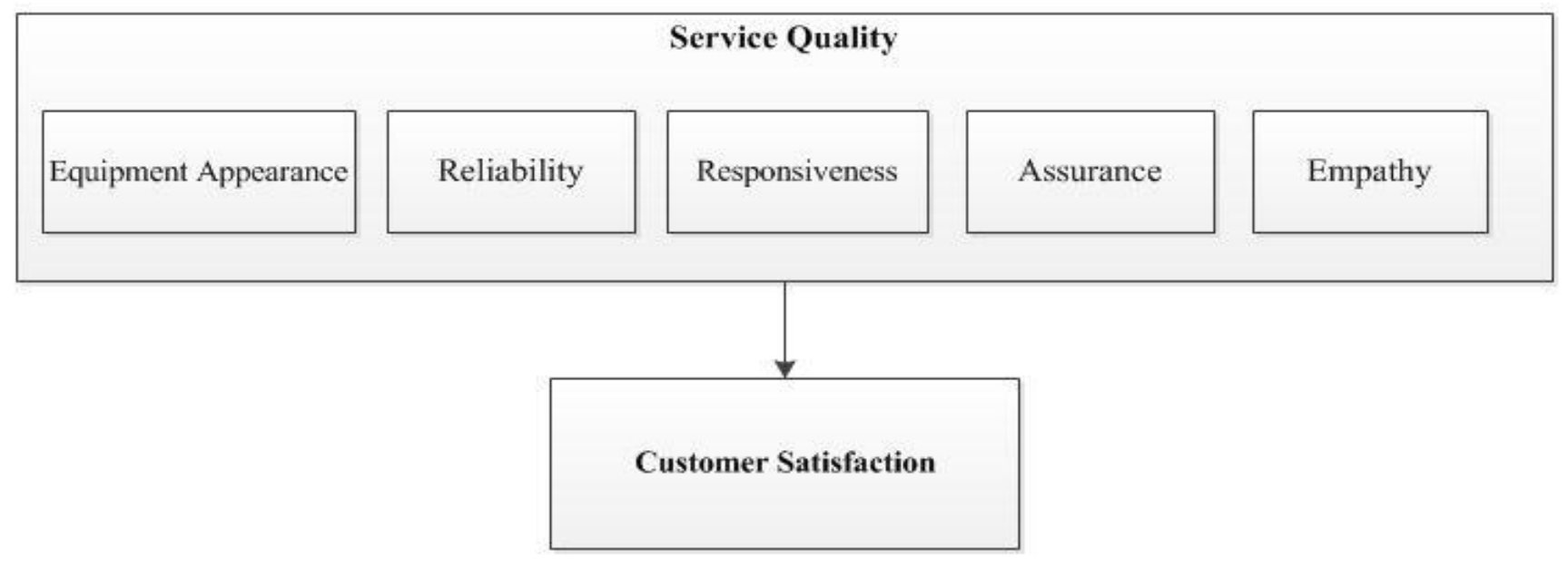




\section{Figure 1 Conceptual Model}

Sampling: In developing this paper, passengers of Kaveh and Sofeh terminals in Isfahan were considered as research population.

In order to do comprehensive evaluation of customer satisfaction, first of all, it is necessary to identify the influential factors from consumer's perspective. To attain this goal the best process is a method named "through the funnel". Thus, a comprehensive list of all the effective features was organized using direct interviews. After that by the method of "through the funnel" the prepared list was edited and the most important factors were remained. Then the questionnaire was designed and pre-test and final revisions were done. By using Cochran formula sample size was determined 200 passengers. Finally by the method of random sampling, questionnaires were distributed among travelers. Respondents were asked not to sign or give any form of identification to ensure the anonymity of their responses.

Measurement: Designed questionnaire contained 3 parts. First part included information about passengers' demographic variables. Other parts of the survey were conducted to measure service quality provided by transportation agencies and passengers' satisfaction.

10 marketing professors evaluated the questionnaire and confirmed its validity. To test reliability of this measurement Cronbach's alpha was used. The total Cronbach's alpha was 0.935 which confirm the scale reliability.

\section{Analysis of participants' demographic variables:}

Based on the results $45 \%$ of passengers were women and $55 \%$ were men.

According to results $16 \%$ of respondents were diploma or under diploma, $38 \%$ had BA degree and $41.5 \%$ had MA and $4 \%$ had PHD.

Based on the results, $64 \%$ of passengers were students, $3 \%$ were university professors, $15 \%$ were employees and $17 \%$ owned other jobs. 
Based on the results $83.5 \%$ of respondents were less than 30 years old, $10.5 \%$ were between 31 to 40 years old and only $5 \%$ of them were 41 to 50 years old and $0.5 \%$ were more than 50 years old.

Collected data showed that $61 \%$ of passengers have been using bus transportation services for less than 5 years, $25 \%$ have been traveling by bus for 6 to 10 years, $6 \%$ have been using bus services for 11 to 15 years, $4.5 \%$ have been traveling by bus for 16 to 20 years and $3 \%$ have been using bus for their trips for 21 to 25 years.

Based on the results $44 \%$ of passengers use Hamsafar Company's services, $10.5 \%$ use Seyr o Safar, 13.5\% use Iran peyma, 7\% use Royal Safar, 17\% use other companies' services and $29.5 \%$ do not care about the compay.

\section{Hypothesis Testing:}

Analysis of H1: Based on the results, observed value for significant factor is less than 0.05, so there is a positive relationship between service quality and customer satisfaction. The Pearson correlation coefficient is 0.271 which confirms the relationship between two variables. (Table 2).It means as the quality of services presented by bus transportation companies increases, the satisfaction of Kaveh and Sofeh terminals' passengers gets highier.

This result indicates that in order to gain competitive advantage, transportation companies must strive to provide high quality services for their passengers and make them satisfied.

\section{Table2- Results of Hypotheses1 Testing}

\begin{tabular}{ccccc}
\hline & & & Service Quality & $\begin{array}{c}\text { Customer } \\
\text { Satisfaction }\end{array}$ \\
\cline { 2 - 5 } $\begin{array}{c}\text { Pearson } \\
\text { correlation } \\
\text { coefficient }\end{array}$ & Service Quality & correlation & 1 & 0.271 \\
& coefficient & & 0.00 \\
& Customer & sig & 0.271 & 1 \\
& correlation & & \\
& & coefficient & 0.00 & \\
\hline
\end{tabular}


- Analysis of H1a: Based on the results, amount of significant factor is less than 0.05 , so $\mathrm{H} 1 \mathrm{a}$ is accepted and there is a positive relationship between equipment appearance and customer satisfaction. The Pearson correlation coefficient is 0.344 which confirms the relationship between two variables.(Table 3). It indicates that as the attractiveness of equipment appearance increases, the level of satisfaction among Kaveh and Sofeh terminals' passengers gets higher.

Table3- Results of Hypotheses1a Testing

\begin{tabular}{ccccc}
\hline & & & $\begin{array}{c}\text { Equipment } \\
\text { Appearance }\end{array}$ & $\begin{array}{c}\text { Customer } \\
\text { Satisfaction }\end{array}$ \\
\cline { 2 - 5 } & Equipment & correlation & 1 & 0.344 \\
$\begin{array}{c}\text { Pearson } \\
\text { correlation } \\
\text { coefficient }\end{array}$ & $\begin{array}{c}\text { Appearance } \\
\text { Customer }\end{array}$ & coefficient & & 0.00 \\
& Satisfaction & correlation & 0.344 & 1 \\
& & coefficient & & \\
\hline
\end{tabular}

- Analysis of H1b: Based on the results, amount of significant factor is less than 0.05, so $\mathrm{H} 1 \mathrm{~b}$ is accepted and there is a positive relationship between reliability and customer satisfaction. The Pearson correlation coefficient is 0.203 which indicates the relationship between two variables.(Table 4)

Table4- Results of Hypotheses1b Testing

\begin{tabular}{|c|c|c|c|c|}
\hline \multirow{4}{*}{$\begin{array}{c}\text { Pearson } \\
\text { correlation } \\
\text { coefficient }\end{array}$} & & & Reliability & $\begin{array}{c}\text { Customer } \\
\text { Satisfaction }\end{array}$ \\
\hline & \multirow[t]{2}{*}{ Reliability } & $\begin{array}{l}\text { correlation } \\
\text { coefficient }\end{array}$ & \multirow[t]{2}{*}{1} & \multirow[b]{2}{*}{0.004} \\
\hline & & sig & & \\
\hline & Customer & correlation & 0.203 & 1 \\
\hline
\end{tabular}




\begin{tabular}{cccc}
\hline $\begin{array}{c}\text { Customer } \\
\text { Satisfaction }\end{array}$ & $\begin{array}{c}\text { correlation } \\
\text { coefficient }\end{array}$ & 0.322 & 1 \\
& sig & 0.00 \\
\hline
\end{tabular}

- Analysis of H1e: Based on the results, amount of significant factor is less than 0.05 , so H1e is accepted and there is a positive relationship between empathy and customer satisfaction.The Pearson correlation coefficient is 0.215 which indicates the relationship between two variables.(Table 7)

Table7- Results of Hypotheses1e Testing

\begin{tabular}{|c|c|c|c|c|}
\hline \multirow{7}{*}{$\begin{array}{c}\text { Pearson } \\
\text { correlation } \\
\text { coefficient }\end{array}$} & & & Empathy & $\begin{array}{l}\text { Customer } \\
\text { Satisfaction }\end{array}$ \\
\hline & \multirow[t]{3}{*}{ Empathy } & correlation & 1 & 0.215 \\
\hline & & coefficient & & \multirow{2}{*}{0.002} \\
\hline & & sig & & \\
\hline & \multirow{3}{*}{$\begin{array}{c}\text { Customer } \\
\text { Satisfaction }\end{array}$} & correlation & 0.215 & 1 \\
\hline & & coefficient & & \\
\hline & & $\operatorname{sig}$ & 0.002 & \\
\hline
\end{tabular}

\section{Conclusion}

The main aim of this study was to investigate the relationship between service quality and customer satisfaction. After analyzing collected data in Spss 19, all of the hypotheses were accepted.

Results showed that reliability and assurance are the most important dimensions of service quality. Thus it is recommended that managers had better pay enough attention to these aspects in order to make passengers more satisfied. It also suggested that transportation agencies must make their services more attractive and also provide proper and on time information for customers. Understanding customers' needs, providing fast and secure services, paying enough 
attention to customers' complaints and faster responsiveness are other factors by which companies can maintain their current customers and attract new ones.

This paper has some limitations as well. Because of the limitation of time and energy this study considered passengers of Kaveh and Sofeh terminals in Isfahan as the research population. This issue may limit the generalizability of results. So future researches can do this study in other cities and compare results with the outcomes of this paper.

\section{References}

-.Beerli A., Martin J.D., Quintana A., (2004);"A model of customer loyalty in the retail banking market", European Journal of Marketing, Vol. 38, No. 1/2, pp. 253-275

-.Swan E. John ,(1982) Consumer Satisfaction Research and Theory: Current Status and Future Directions, International Fare in Consumer Satisfaction and Complaining Behavior, pages: 124-129.

-.Jafari, J., (2002). Encyclopedia of tourism ,London \& New york, Rout ledge

-.O.A.budiono, 2009. Customer statisfaction in public bustransport, a study of travelers perception in Indonesia. Karlstad university, Sweden

-.C.buchanan\&partner, 2004, bus passenger satisfaction 2003. Scottish executive social research

-. Buttle, F. (1996). SERVQUAL: review, ctirique, research agenda. European Journal of Marketing , 30, 832

-. Zhu, F., Wymer Jr, W., \& Chen, I. (2002). IT-based services and service quality in consumer banking. International Journal of Service Industry Management , 69-90.

- Mirghafuri H,Maleki F[Educational library services quality (Case: Yazd University Libraries) approach

LibQual].[ Library and information science magazines];2008, 10 (1): pp. 62-79.[Persian]

-. Ravichandran K, Prabhakaran S, Arun Kumar S. Application of Servqual Model on Measuring Service

-Quality. A Bayesian Approach. Enterprise Risk Management 2010; 1(1).

-. Siadat Seyed H. Measuring Service Quality Using Servqual Model: A Case Study Of E-Retailing In Iran. 
-[Thesis], Malaysia: Faculty of Computer Science and Information System University Technology; 2008.

-.Kotler, P., \& Armstrong, G. (1999). Principles of Marketing ( $8^{\text {th }}$ ed.). New Jersey, USA: Pretice Hall Inc

-.Arasli, H., Katircioglu, S., \& Samadi, S. (2005). A Comparison of service quality in the banking industry,some evidence from Tuskish- and Greek- speaking areas in Cyprus. International Journal of Bank Marketing , 23, 508-526.

-.Holdford david (2003), Identificaation of the Service Quality of Pharmaceutical Education, Department of Pharmacy. Virginal common wealth University, American Journal of Pharmaceutical Ed., 67(4) Article 108

- Pfaff Martin (1976), The Index of Consumer Satisfaction: Measurement, Problems, and Opportunities, Conceptualization and Measurement of Consumer Satisfaction, Dissatisfaction, and Complaining Behavior, Pages:

36-71.

-Erevelles Sunil and Leavitt Clark (1992), Comparison of Current Models of Consumer Satisfaction/Dissatisfaction, Journal of Consumer Satisfaction, Dissatisfaction and Complaining Behavior, VOL.5, pages: 104-114.

-Arasli, H., Katircioglu, S., \& Samadi, S. (2005). A Comparison of service quality in the banking industry,some evidence from Tuskish- and Greek- speaking areas in Cyprus. International Journal of Bank Marketing , 23, 508-526.

-Mishkin, F. (2001). The economics of money, banking and financial markets (6th ed.).

-Sadiq Sohail, M., \& Shaikh, N. M. (2008). Internet banking and quality of service. Online Information Review, 32, 58-72. 